\title{
The Development of Reflective-Scientific Learning Model to Improve 21st Century Learning Skills In Historical Learning
}

\author{
Musa Pelu* \\ Universitas Sebelas Maret \\ *Corresponding author`s e-mail: pelumusa@yahoo.com
}

\begin{abstract}
Abstrak: Penelitian ini bertujuan untuk mengembangkan Model Pembelajaran Reflektifilmiah untuk mengakomodasi keterampilan pembelajaran abad 21 dalam pembelajaran sejarah. Desain pembelajaran ADDIE digunakan sebagai metode penelitian untuk mengembangkan model pembelajaran. Partisipan penelitian adalah 120 siswa SMA. Model Pembelajaran Reflektif-ilmiah terdiri dari lima tahap pembelajaran: keterlibatan sejarah, eksplorasi kritis, penjelasan komunikatif, elaborasi kreatif, dan evaluasi reflektif. Hasil penelitian membuktikan kelayakan dan keefektifan model pembelajaran yang dikembangkan dalam meningkatkan keterampilan belajar abad 21 siswa pada proses pembelajaran sejarah. Artinya model pembelajaran yang dikembangkan dapat mengakomodir kebutuhan keterampilan belajar abad 21 dan tujuan pembelajaran sejarah. Berdasarkan penelitian ini, penulis menyoroti bahwa penjabaran model pembelajaran dapat memberikan ruang untuk menyelaraskan tujuan pembelajaran sejarah dengan konsep pendidikan lain dari berbagai disiplin ilmu. Dengan demikian, penelitian dan pengembangan lebih lanjut dalam lanskap pendidikan sejarah harus memberikan lebih banyak kesempatan untuk mengelaborasi model pembelajaran untuk mengubah peran dan dampak pembelajaran sejarah di abad ke-21.
\end{abstract}

Kata kunci: reflektif-ilmiah; keterampilan super 4C; history

Abstract: This research aims to develop the Reflective-scientific Learning Model to accommodate 21st-century learning skills in learning history. The ADDIE instructional design was used as the research method to develop the learning model. The research participants were 120 senior high school students. The Reflective-scientific Learning Model consists of five learning stages: historical engagement, critical-exploration, communicative-explanation, creative-elaboration, and reflective evaluation. The research results prove the feasibility and effectiveness of the developed learning model in improving students' 21 st-century learning skills in the learning history process. It means that the developed learning model can accommodate the needs of the 21st-century learning skills and the learning history objectives. Based on this research, the authors highlight that the elaboration of the learning model can provide a space for synchronizing learning history objectives with other educational concepts from various disciplines. Thus, further research and development in the history education landscape should provide more opportunities for elaborating the learning models to amend the role and impact of learning history in the $21^{\text {st }}$ century.

Keywords: Reflective-scientific; the 4Cs super skills; history

\section{Introduction}

The rapid development of technology and the coming of the fourth industrial revolution have triggered fundamental changes in the practice of learning history. Today, the history teachers have to accommodate the needs of the 21st-century learning that substantively has different characteristics from the learning history objectives. Consequently, the development of an advanced learning model for learning history is needed to support teachers' and students' activities in 21st-century historical learning. Theoretically, the main objective of the learning history is to instill historical consciousness to students (Lee, 1991; 
Shemilt, 2018). Historical consciousness refers to students' ability to manage temporal dimensions (Van Straaten, Wilschut, \& Oostdam, 2016). Historical consciousness provides a futuristic insight for the students to expand their perspective throughout the past, present, and future (Ahonen, 2005; Thorp, 2014). The learning history also has social and moral responsibilities to shape national identity and nurture wisdom to students (Seixas, 2017). Those objectives demand students' ability to take reflections of the past event and bring it to the present and future contexts. The reflective learning approach plays an essential role in learning history, especially connecting some issues throughout the temporal dimension. The reflective learning approach helps the students reflect on past events based on the emotional senses (Ghaye, 1988).

On the other side, the 21st-century learning paradigm tends to educate students to acquire futuristic skills such as 4Cs Super Skills that consist of students' ability to think critically and solve the problem, communicate actively in society, collaborate with the partners, and use creativity and make innovation (Kivunja, 2014b). These relate to the demanded skills in the fourth industrial and the globalized society that employs technological work and digital economy (National Education Association, 2014; Ozola \& Reimere, 2015). Among many contemporary learning approaches, scientific learning matches the direction of

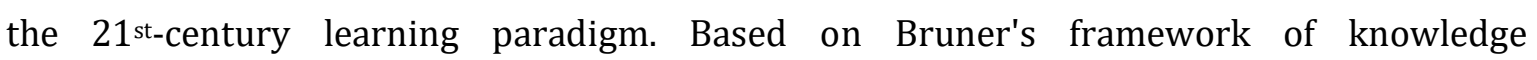
construction, the scientific approach trains the students to examine, explore, explain, elaborate, and evaluate the learning topic. The scientific learning approach emphasizes inquiry processes such as the scientist activities in laboratories (Deboer, 2006; Bybee, 2006). Kivunja (2015) perceived that these scientific activities are in line with the needs of 4Cs Super Skills. Scientific activities in the classroom cultivate students' critical thinking, communication, collaboration, and creativity when examining scientific problems presented in the learning process.

From the above descriptions, some problems related to learning history in the $21^{\text {st }}$ century appeared. First, 21st-century learning skills locate beyond the objectives of learning history. As mentioned before, the aims of learning history relate to the students' historical consciousness encompassing the students' ability to perceive the future of human life. Meanwhile, 21st-century learning skills aim to train the students to master futuristic skills to think critically, solve the problem, communicate, collaborate, and make innovation. Second, there are no distinctive practical concepts either in the history education or $21^{\text {st-century }}$ learning history objectives. The existing models and strategies in learning history emphasize to enhance students' ability to understand the past and discover values and wisdom from 
historical events. The futuristic skills can implicitly learn through the lens of historical consciousness that provides a space for the student to perceive the future based on the past. Other futuristic skills, such as critical thinking, communication, and creativity, are generated from reflection and contextualization in the learning history process. These skills are in the outward of the existing learning history model. For instance, students learn about the history of World War II. Using the sense of historical consciousness, the students can take a future perspective that they will fight against the wars and genocides in the future. The students will think critically about the possibilities of wars in the future and its consequences for the human race. The students perhaps will not be able to train their communication, collaboration, and creativity in this learning topic. Except teachers can provide a specific learning model to support the communication, collaboration, and creativity of students in the classroom. Therefore, in this case, students can get only the values from the history of World War II.

The authors assume that the development of an advanced learning model of history can solve those problems. As suggested by The National Education Association (2014), the educators and educational developers have to develop an advanced learning model following the needs of 21st learning skills. Moreover, Henn-Reinke and Chesner (2014) suggested elaborating various learning strategies or approaches into an appropriate learning model that can accommodate every learning subject's characteristics. Based on these suggestions, the learning history model should be elaborated with other components from different disciplines to accommodate 21st-century learning demands. This elaboration will rejuvenate the impact as well as the role of learning history in contemporary education. From the authors' perspective, the elaboration can be conducted at the practical level by developing a learning model that accommodates the needs of the $21^{\text {st }}$ learning skills and the learning history objectives.

The researchers or developers in the field of history education should try to

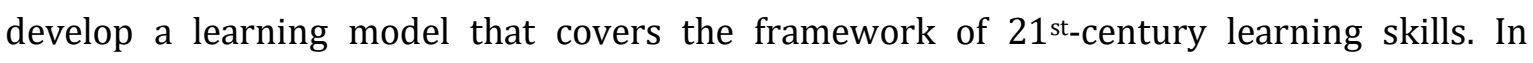
general, some scholars such as Kivunja (2015) and Miller (2016) have developed a learning model that meets 21st-century learning skills requirements. Kivunja (2015) and Miller (2016) have initiated instructional learning development based on Bruner's conception of knowledge construction to teach the 4Cs Super Skills in the classroom. Kivunja integrated the 4Cs Super Skills and Bruner's 5E learning stages that consist of five stages: engagement, exploration, explanation, elaboration, and evaluation. However, the authors perceive that this general learning model is inadequate to meet various characteristics of learning subjects. Kivunja's learning model was not designed only for learning history that deals with the 
temporal dimension of the past, present, and future. Implementing Kivunja's learning model in learning history can be a challenging activity for teachers and students. It means that Kivunja's instructional models perhaps could not be fully implemented in the particular subjects of learning, such as the historical subjects. Based on the above description, this research aims to develop the Reflective-scientific Learning Model to accommodate the needs of 21st-century learning skills in learning history. In this developed model, the authors try to elaborate on the scientific learning approach and reflective learning approach. The authors assume that scientific and reflective learning approaches provide a space to promote 4Cs super skills in learning history by supporting the students' inquiry and reflection. The elaboration can rejuvenate the role and impact of learning history in the $21^{\text {st }}$ century.

\section{Method}

Peneliti The authors used the Research and Development (R\&D) method to design, develop, and evaluate the Reflective-scientific Learning Model. The design of research based on ADDIE (Branch, 2010) instructional design and Reigeluth and Carr-Chelman's (2009) framework of learning instruction elaboration.

1. Research Design

ADDIE instructional design consisted of five stages: Analyze, Design, Development, Implementation, and Evaluation. In the Analyze stage, the authors examine the instructional gaps between the framework of learning history and the scientific learning approach. Based on the gap analysis, the authors designed a blueprint of the developed model based on scientific learning approach and reflective learning. The authors designed a blueprint of the developed model by using Reigeluth \& Carr-Chellman (2009) framework of instructional elaboration that covers five activities, namely selecting all the operations to be taught, decide which operation to teach first, sequence all the remaining operations, create all expanded epitomes, and design instruction on each operation. In the developmental stages, the authors conducted two types of test trials, one-one trial, and small group trials, to determine the potential of the feasibility of the developed model. This stage aimed to minimize the fundamental errors in the developed model. Furthermore, the authors implemented and evaluated the developed model in the field trial process. These stages aimed to assess the effectiveness of the developed model in improving the super skills in learning history.

2. Research Participant

The research participants were 120 students of Senior High Schools. They participated as the respondent in the Development, Implementation, and Evaluation stages to look at the practicality and feasibility of the developed model. The research participants were 
aged between 17 to 18 years old, consisted of 76 male students and 44 female students. In the one-one trial, five students participated and gave their perspective to the developed model. Meanwhile, 30 students were participated and gave their perspective in the small group trial. In the field trial, 120 students participated in testing the effectivity of the developed model.

3. Instrument and Techniques of Data Collection

The instruments used in this research were the attitude questionnaire and the 4Cs super skills assessment. In the development stage, especially in the one-one trial and small group trial, the data were collected through students' attitude questionnaires towards the feasibility of the developed model in the learning history. The questionnaire consisted of three aspects of students' perception of the organization, the format, and the quality of the developed model. The students filled the questionnaire after the implementation of the model in the classroom. The score of students' questionnaires was considered to do the summative revision of the developed model.

Furthermore, in the field trial, the data were collected through the 4Cs super skills assessment composed by authors. The 4Cs super skills assessment consisted of 15 question items with four aspects of super skills: creativity, communication, collaboration, and critical thinking. This instrument of the 4Cs super skills was tested for its validity and reliability through SPSS Program. After that, the instrument was used to assess students' super skills in the evaluation stage. The result of the validity test showed that 15 question items were valid. The result of the reliability test was 0.633 , which means the question items were reliable. It means the result of the validity test and reliability test through the SPSS Program showed that the 4Cs super skills questionnaire were valid and reliable. Thus, this instrument could be used to assess the 4Cs super skill improvement after the implementation of the developed model.

4. Data analysis

The one-one trial and small group trials were analyzed through quantitative and qualitative analysis to minimize the errors and assess the feasibility of the developed model. To measure the feasibility of the model, the authors used the product feasibility criteria of Sutimin, Joebagio, Sariyatun, and Abidin (2018) and Ningsih, Sariyatun, and Sutimin (2019). Table 1 informs the product feasibility criteria. 
Table1. Product feasibility criteria

\begin{tabular}{ll}
\hline Range & Criteria \\
\hline $3.26-4.00$ & Very feasible \\
$2.51-3.25$ & Feasible \\
$1.76-2.50$ & Feasible enough \\
$1.00-1.75$ & Not feasible \\
\hline
\end{tabular}

Furthermore, in the evaluation stages, the data were analyzed quantitatively through the paired-sample t-test by comparing the score of the students' 4Cs super skills in the pre-test and post-test of the field trials. In comparing the scores, the authors used the SPSS Program in order to get the data of effectivity of the developed model in improving students' scores of the 4Cs super skills.

\section{Result and Discussion}

\section{A. Result}

\section{The result of the Analysis Stage}

The authors found a gap between the learning objectives of history subjects and the framework of 4Cs Super Skills. The objectives of learning history consist of three-dimension, namely historical knowledge, historical thinking, and historical consciousness. Historical knowledge refers to students' understanding of the subject of learning that covers the conceptual and theoretical understanding of historical events (Husband, 2011). Historical knowledge relates to historical and procedural aspects. In historical studies, historical knowledge plays an essential role as the basis of historical thinking, historical inquiry, and historical reasoning (Mandelbaum, 2019). It is socially constructed by society and covers humans' cognitive processes to deal with the past (Wamba-dia-Wamba, 1986).

Another objective learning history is to construct students' historical thinking. Historical thinking refers to students' ability to think like a historian. According to Seixas (2017), historical thinking consists of five major components: historical significance, understanding primary source evidence, understanding continuity and change, understanding cause and consequence, historical perspective-taking, and understanding ethical dimension. The first aspect of historical thinking relates to historical significance. Historical significance means that the students should acknowledge the importance of a particular event in the past to become historical events. Students should understand that historical events have a distinctive character and significance for present society. The second aspect of historical thinking is the understanding of primary source evidence. These skills 
refer to students' skills to conduct evidence when they deal with the primary source. This ability covers the skills to understand the text and the context of historical sources. The third aspect of historical thinking is the understanding of continuity and change. Understanding continuity and change become key questions in learning history. By understanding continuity and change, the students can get answers about society's dynamic in the temporal dimension. The fourth aspect of historical thinking is the understanding of cause and consequence. Understanding the cause of consequence is an essential aspect of historical explanation. This skill relates to students' ability to explain the sequential aspect of events in learning history. The fifth aspect of historical thinking is historical perspective-taking. This skill relates to the students taking perspectives of the past. By taking a historical perspective, the students can get historical sense used to understand more deeply historical events in learning history. The sixth aspect of historical thinking is the understanding of the ethical dimension from historical events. The ethical dimension consists of three aspects: the students' judgment on the historical actors and actions, the ethical aspect of the legacy of crimes and injustice in the past, and the memorial obligations of heroes and heroisms that are useful from the present society.

The third objective of learning history is historical consciousness. Historical consciousness refers to students' ability to connect the past, present, and future. Thorp (2014) stated two fundamental aspects of historical consciousness: historical thinking and historical cognition. The relation between historical consciousness and historical thinking lies in its role in constructing a meta-theoretical analysis of historical events. It means that historical thinking provides a way for the students to analyze and sense historical events that bridge the temporal dimension into sequential processes (Lee, 2006; Shemilt, 2000). Historical cognition refers to the process of prospective and retrospective contextualization of historical events. Similar to historical-perspective taking, students can get a deeper understanding of historical events (Thorp, 2014). Based on those definitions, the nature of history learning covers students' ability to deal with historical events. It means that after learning history, the students should have an understanding of historical events, understand the way of historians in perceiving the past, and also have an ability to connect the temporal dimension from the past, present, and future.

Meanwhile, 21st super skills consist of five aspects: critical thinking, communication, collaboration, creativity, and innovation. The 4Cs Super Skills organized as the general construction of 21st-century learning. It derived from the socio-constructivism approach learning paradigm (Kivunja, 2014a). Based on the National Education Association (2014), the components of the 4Cs are as follows: 
Table2. The Characteristic of 4Cs Super Skills

\begin{tabular}{ll}
\hline \multicolumn{1}{c}{ Skills } & \multicolumn{1}{c}{ Characteristics } \\
\hline Critical thinking & Making a reason effectively, using system thinking, making a \\
& judgment and decision, solving the problem \\
Communication & Communicating clearly with other students \\
Collaboration & Collaborating with other students \\
Creativity and innovation & Thinking creatively, work creatively with others, implement \\
& innovation \\
\hline
\end{tabular}

Based on the result of the analysis, the authors highlighted that the nature of learning history and the 21st century super skills, the authors found that the gap lies in the incapability of the 4Cs Super Skills to cover the temporal dimension and the social context of history subject. As it appears in table 2, the framework of 4Cs Super Skills did not emphasize on the specific nature of any learning subjects. It was designed as the grand framework to accommodate the character of 21st-century learning and education. On the other hand, learning history has specific objectives and natures that could not be accommodated directly from the 21st-century learning model's design. Ahonen (2004) and Thorp's (2014) research explicitly mentioned that only the aspects of historical consciousness provide a space to nurture future skills in the learning history process. Historical consciousness provides the futuristic dimension for the students to expand their horizons from the past, present, and future. Based on that analysis, the authors found the possible gap between the nature of history and the demand for 21st-century learning that lies in their inability to calibrate into an integrated learning process. An effort to calibrate the nature of learning history and the demands of the 21st-century learning was necessary to do. From the authors' perspective, the elaboration of the reflective and scientific learning approach can minimize the gap. The result of the analysis stages becomes a basis for designing the development model in the design stage.

\section{The Result of Design Stage}

To fill the gap between the objective of learning history and the demands of 21stcentury learning, the authors considered using a scientific learning approach and a reflective learning approach to enclosing the 4Cs super skills with the nature of history subject. The instructional learning of the scientific approach is identical to the scientist's works (Deboer, 2006) that accentuates the inquiry through the scientific teaching and learning (Bybee, 2006), scientific argument (Kuhn, 1993), or scientific literacy (DeBoer, 2000). Commonly, the 
$5 \mathrm{E}$ instructional model that consists of five learning stages, namely, engagement, exploration, explanation, elaboration, and evaluation, represents the scientific learning approach (Bybee, 2006). The specific activities of each learning stages of scientific instructional learning model are as follow:

Table 3. The activities of the scientific instructional model

\begin{tabular}{|c|c|}
\hline Learning stages & Activities \\
\hline Engagement & $\begin{array}{l}\text { - Teacher and students engage with the learning material } \\
\text { - Teacher anticipate activities and focus students' thinking on the } \\
\text { learning outcomes of current activities }\end{array}$ \\
\hline Exploration & $\begin{array}{l}\text { - Students actively explore their environments or manipulate the } \\
\text { material }\end{array}$ \\
\hline Explanation & $\begin{array}{ll}- & \text { Students verbalize their exploration experience } \\
\text { - } & \text { Teachers introduce a concept, definition, or theory }\end{array}$ \\
\hline Elaboration & $\begin{array}{l}\text { - Students extend their conceptual understanding and practice } \\
\text { their desired skills and knowledge }\end{array}$ \\
\hline Evaluation & $\begin{array}{l}\text { - Students assess their understanding and abilities } \\
\text { - The teacher evaluates the progress of learning towards the } \\
\text { achievement of educational objectives. }\end{array}$ \\
\hline
\end{tabular}

From those learning stages and activities in table 3, the authors found that the scientific learning demands the production of students' scientific argumentations, which relates to students' critical thinking, communication, collaborative activities, and creativity. This learning approach becomes an ideal learning approach to improve students' scientific thinking and super skills. However, the scientific learning approach does not provide a space for reflection that becomes fundamentally important for learning history. Therefore, the authors added some elements of the reflective learning approach in the developed model. Reflective learning consists of two overlapping processes of reflection and practice that operates based on the emotional senses (Ghaye, 1988). Moon (2004) has posited the reflective learning inside of Kolb experiential learning stages: concrete experience, abstract conceptualization, reflection, and actual learning results. Moon then described two main stages inside of reflective learning. Table 4 informs the stage of reflective learning. 
Table 4. The stages of reflective learning

\begin{tabular}{lll}
\hline Stages & Activities \\
\hline Presenting & - & Considering the definition of reflection, reflective writing, reflective \\
reflection & & learning \\
& - & Generating discussion of learners' conception of reflection \\
& - & Enabling practice and opportunities for feedback \\
& - & Giving a starting exercise that eliminates the blank page \\
& & learning activities \\
& - & Setting up the situation in which learners can share their ideas \\
& - & Supporting some learners more than others \\
\hline Deepening & - & Serm of learning \\
reflective & - & Introducing a framework that describes levels of reflection \\
activities & - & Introducing exercises of self-actualization \\
& - & Introducing exercises that involve reflection on the same subject \\
& & matter from different viewpoints of people or social institution \\
& - & Introducing exercise that involves reflection that is influenced by \\
& & emotional reactions to events \\
& - & Introducing methods of deepening reflection by working with other \\
\hline
\end{tabular}

Table 4 shows that the objectives of reflective learning related to self-correct and self-supervision. In the context of the learning history, the reflective learning approach provides a space for social reflection in learning history instead of emphasizing the cyclical process. This means the reflective learning approach can provide a tool for the students to contextualize the past event and bring it into the present time. Based on these analyses, the scientific and reflective approach can encourage historical inquiry and historical reflection of students. The students will have space to create an argumentation, scientific skills, super skills and reflecting them into the present time. The authors integrated 4Cs Super Skills, the scientific learning approach, and the reflective learning approach into a reflective-scientific learning model matrix. This matrix designs as the blueprint for the developed model. The authors used Reigeluth and Carr-Chellman's (2009) framework. Table 5 informs the detail explanation of the matrix.

Table 5. The matrix of the Reflective-scientific Learning Model (SRLM)

\begin{tabular}{llll}
\hline \multicolumn{1}{c}{$\begin{array}{c}\text { Stages of } \\
\text { SRLM }\end{array}$} & Scientific learning & \multicolumn{1}{c}{$\begin{array}{c}\text { 4Cs } \\
\text { super skills }\end{array}$} & $\begin{array}{l}\text { Historical- } \\
\text { Reflective } \\
\text { Learning }\end{array}$ \\
\hline Historical engagement & Engagement & $\begin{array}{l}\text { Critical thinking } \\
\text { collaboration }\end{array}$ & $\begin{array}{l}\text { Presenting } \\
\text { reflection }\end{array}$ \\
\hline Critical Exploration & Exploration & Communication & \\
\hline $\begin{array}{l}\text { Communicative } \\
\text { explanation }\end{array}$ & Explanation & Creativity Innovation & $\begin{array}{l}\text { Deepening } \\
\text { reflection }\end{array}$ \\
\hline $\begin{array}{l}\text { Creative-reflective } \\
\text { elaboration }\end{array}$ & Elaboration & & \\
\hline
\end{tabular}


Reflective evaluation Evaluation activities

The matrix was then derived into a learning syntax that consists of a detailed description of the learning activities in the developed model. Table 6 describes the learning syntax of the Reflective-scientific learning model.

Table 6. The learning syntax of Reflective-scientific Learning Model (SRLM)

\begin{tabular}{|c|c|}
\hline Stages of SRLM & Scientific learning \\
\hline $\begin{array}{l}\text { Historical } \\
\text { engagement }\end{array}$ & $\begin{array}{l}\text { The teacher and students initiate engagement with the past and } \\
\text { connect with the present context by taking a particular perspective }\end{array}$ \\
\hline \multirow[t]{2}{*}{ Critical Exploration } & $\begin{array}{l}\text { The students collectively explore, reasoning, and judging the data } \\
\text { from primary and secondary historical source }\end{array}$ \\
\hline & $\begin{array}{l}\text { The students verbalize their findings, feedback, and reflection of } \\
\text { exploration in the classroom. }\end{array}$ \\
\hline \multirow[t]{3}{*}{$\begin{array}{l}\text { Communicative } \\
\text { explanation }\end{array}$} & $\begin{array}{l}\text { The teacher presents a concept, definition, or theory and gives } \\
\text { feedback to the students' findings and reflections. }\end{array}$ \\
\hline & $\begin{array}{l}\text { The students share their different ideas and perspectives based on } \\
\text { their findings and reflection. }\end{array}$ \\
\hline & $\begin{array}{l}\text { The students use an analogical and example of extending their } \\
\text { conceptual understanding and practicing their desired skills and }\end{array}$ \\
\hline \multirow[t]{3}{*}{$\begin{array}{l}\text { Creative-reflective } \\
\text { elaboration }\end{array}$} & $\begin{array}{l}\text { knowledge by formulation a historical understanding and historical } \\
\text { explanation. }\end{array}$ \\
\hline & $\begin{array}{l}\text { Teachers introduce frameworks that describe the level of students' } \\
\text { creative-reflective elaboration ability. }\end{array}$ \\
\hline & $\begin{array}{l}\text { The students assess their historical understanding, self- } \\
\text { actualization. }\end{array}$ \\
\hline \multirow[t]{2}{*}{ Reflective evaluation } & $\begin{array}{l}\text { The students give subjective and emotional reaction towards the } \\
\text { historic event. }\end{array}$ \\
\hline & $\begin{array}{l}\text { The teacher evaluates the progress of learning towards the } \\
\text { achievement of educational objectives. }\end{array}$ \\
\hline
\end{tabular}

\section{The result of the development stage}

The development stage consisted of one-one trials and small group trials. The authors assess the result of one-one trials and small group trials through the students' attitude questionnaires. Table 7 informs the result of the development stage.

Table 7. The result of one-one trial and small group trials

\begin{tabular}{|c|c|c|c|c|c|c|}
\hline Trial stages & $\begin{array}{c}\text { Number of } \\
\text { participants }\end{array}$ & Organization & Format & Quality & Average & Criteria \\
\hline One-one trial & 5 & 3.6 & 3.2 & 2.6 & 3.13 & Feasible \\
\hline $\begin{array}{l}\text { Small group } \\
\text { trial }\end{array}$ & 30 & 2.85 & 2.9 & 3.15 & 2.96 & Feasible \\
\hline
\end{tabular}

Besides conducting one-one and small group trials, the authors also conducted a summative revision based on students' comments to minimize the fundamental errors of the developed model. Overall, the students stated that they could follow the learning stage of the developed model. However, in a one-one trial, the students thought that the learning preparation took much time. As a result, the developed model could not be well implemented 
in the learning process. Meanwhile, the students stated that they need more time in the critical exploration stages, especially in exploring historical data. Based on the students' comments, the authors then revise the time proportion in the developed model by giving additional time to the critical exploration stages. In sum, based on the results of the one-onone and small-group trials, the authors highlighted that the developed model was feasible. Therefore, the developed model could be implemented and evaluated in the next stages of development.

\section{The result of implementation and evaluation stages}

The authors conducted a field trial in the implementation and evaluation stages. The authors assessed the effectivity of the developed model through pre-test and post-test analysis. Table 7 informed the result of the field trial.

Table 7. The result of the field trial

\begin{tabular}{|lllrrr|}
\hline & Mean & N & Std. Deviation & Std. Error Mean \\
\hline Pair 1 & Pre-test & 39.76 & 120 & 3.644 & .333 \\
& Posttest & 44.99 & 120 & 3.556 & .325 \\
\hline
\end{tabular}

Table 7 shows that the mean of the pre-test score was 39.76; meanwhile, the mean of the post-test score was 44.99. From the mean scores, the post-test score was higher than the pre-test score.

Table 8. The result of the paired sample test

\begin{tabular}{|c|c|c|c|c|c|c|}
\hline \multicolumn{7}{|c|}{ Paired Samples Test } \\
\hline & \multicolumn{5}{|c|}{ Paired Differences } & \multirow{3}{*}{$\begin{array}{l}\text { Sig. (2- } \\
\text { tailed) }\end{array}$} \\
\hline & \multirow[b]{2}{*}{ Mean } & \multirow{2}{*}{$\begin{array}{c}\text { Std. } \\
\text { Deviation }\end{array}$} & \multirow{2}{*}{$\begin{array}{l}\text { Std. Error } \\
\text { Mean }\end{array}$} & \multicolumn{2}{|c|}{$\begin{array}{c}95 \% \text { Confidence Interval of } \\
\text { the Difference }\end{array}$} & \\
\hline & & & & Lower & Upper & \\
\hline $\begin{array}{ll}\text { Pair } & \text { Pre-test - } \\
1 & \text { Post-test }\end{array}$ & -5.233 & 4.505 & .411 & -6.048 & -4.419 & .000 \\
\hline
\end{tabular}

According to table 8, the difference of mean between pre-test and the post-test scores was -5.233 . The mean of the post-test (44.99) was higher than the mean score of the pre-test (39.76). It means that the score of the post-test was higher than the sore of the pretest. Moreover, the value of Sig. $(2$-tailed) was $0.000(p<0.05)$, which shows a significant 
difference between the pre-test and post-test. Based on the research results, the developed model can be implemented in the learning history process. The feasibility and effectivity of the developed model could be proved by the one-one trial score, and a small group trial and paired sample t-test prove the feasibility. Based on those scores, the SRLM model of learning history was feasible to be implemented in learning history, and it can be used by history teachers to improve the students' 4Cs super skills.

\section{B. Discussion}

Pada The research results show that the Reflective-scientific learning model is feasible to use in the classroom. The developed model elaborates scientific and reflective learning approaches in its learning syntax. The component of the scientific approach provides a space to enhance students' critical thinking and creativity that relates to the process of inquiry (Deboer, 2006; Kuhn, 1993). The component of the reflective approach accommodates the students to contextualize the learning material in history subject, which almost narrates past events to the present contexts (Phillips, 2008). Based on those approaches, the demand for the 21st-century learning process to promote 4Cs super skill and the nature of history subject can be accommodated in the developed learning model.

In comparison with other learning models, which are mainly constructed based on the reflective approach or scientific approaches, such as Phillips (2008) and Percival (2013), the developed model aims to construct scientific thinking and reflective ability rather than drawing explanation on teaching strategies to become more reflective in teaching history. Although it takes a different framework, the model accommodates previous suggestions in constructing the reflective ability of teachers. Phillips (2008) suggests emphasizing teachers' taking perspective as the basis of reflective teaching. The developed model accommodated this suggestion, especially in the historical engagement in which the students start taking perspective in analyzing historical data and constructing narratives in the learning process. However, the developed model's framework emphasizes students' taking perspective rather than the teachers' ability to teach reflective learning. Moreover, Phillips (2008) also mentioned three essential requirements in establishing reflective teaching: focused inquiries, proper use of primary historical sources, and the level of difficulties of students' tasks. Those requirements established in the developed, particularly in the stages of historical engagement and critical exploration.

Moreover, Percival (2013) suggested presenting contradictions in the learning process to trigger students to organize the contradictory data by using their critical and analytical thinking. The presence of contradictory data in the learning process means 
challenges for the students. Some activities in the phases of critical-exploration, communicative explanation, and creative-reflective elaboration represent students' challenges. In the stages of critical-exploration, communicative explanation, and creativereflective elaboration, students learn how to use their critical thinking skills and creative skills. In the critically-exploration, students collectively explore the data and make reasoned and judging the data from primary or secondary resources. In this stage, the students can deal with many contradictions in exploring and analyzing historical resources. Meanwhile, in the communicative explanation and creative-reflective elaboration stages, students extend their conceptual understanding of historical knowledge and historical explanation. Both stages support student investigation and also argumentative skills. In the three earlier stages of the developed model, students use their reflection ability during engagement, exploration, and explanation to examine the historical resources. In those stages, students can generate feedback, deepen analysis, and support other students during the learning process. In the last two stages of the developed model, namely creative-reflective elaboration and reflective evaluation, students take a reflection to expand their understanding and emotional tendency about the learning topic.

The above discussion shows that the combination of scientific and reflective learning approaches can potentially enhance students' reflective thinking and students' super skill in learning history. Perceiving from Ghaye's (1988) perspective, the five stages of the developed model provide a reflective process based on the emotional sense that leads the students to give a space for social reflection of historical learning. The scientific approach trains the students to strengthen their critical thinking, communication, collaboration, and creativity. Meanwhile, the reflective approach solves the temporary problem by helping the students to contextualize past events into the present context and then supports the students' opportunity to achieve 4Cs Super Skills in the learning process. It means that the developed model can be posited as an advanced learning model of learning history that provides a space for social reflection and critical thinking in learning history.

The developed model can synchronize the nature of history subject with the framework of 21st-century learning that demands the improvement of the students' future skills. From the authors' perspective, this research brings a theoretical and practical impact according to the space of elaboration or combination of components following the demand for 21st-century learning. This research supports the National Education Association (2014) and Henn-Reinke and Chesner's (2014) suggestion that educators should try to elaborate a multidisciplinary approach to accommodate the demands of 21st-century learning. The 
authors believe that, shortly, the elaboration or combination of the multidisciplinary aspects of learning subject or theory can become a common trend in the educational field. This research shows that the demands of the 21st-century learning can be accommodated by elaborating the learning process besides of other processes such as the elaboration of conceptual knowledge (Van Boxtel, C., Van der Linden, J., \& Kanselaar, G., 2000) and the elaboration of learning skills (Weinstein, 1978; McComb, 2017). This research proves that the nature of learning history can be calibrated with the 4Cs super skill by elaborating the scientific learning approach, which consists of five activities supporting the 4Cs Super Skills, and reflective learning approach, which give the students a space to reflect and dynamically connect the temporal dimension. Practically, the developed model can be used as an advanced learning model for learning history in the 21st century because of its ability to calibrate the demands of 21 st-century learning in the learning history process.

\section{Conclusion}

The Reflective-scientific Learning Model consists of five learning stages: historical engagement, critical exploration, communicative explanation, creative-reflective elaboration, and reflective evaluation. The developed model provides a space for the 4Cs Super Skills improvement as the 21st century super skills and the nature of the historical subject that deals with the historical event. This research shows that the distinctive learning model should be developed for each learning subjects following the demand for 21st-century learning. In the context of learning history, the 21st-century learning model should be accommodated the nature and characteristics of history education. Therefore, further research should focus on the synchronization of 21st-century learning skills and the objectives of learning history based on the utilization of other aspects of learning. The development of the learning model can rejuvenate the role and position of learning history in the $21^{\text {st }}$ century.

\section{References}

Ahonen, S. (2005). Historical consciousness: a viable paradigm for history education? Journal of Curriculum Studies, 37(6), 697-707.

Branch, R. M. (2010). Instructional design: The ADDIE approach. Instructional Design: The ADDIE Approach. https://doi.org/10.1007/978-0-387-09506-6

Bybee, R. W. (2006). Scientific inquiry and science teaching. In scientific inquiry and nature of science (pp. 1-14). Springer.

Deboer, G. E. (2006). Historical perspectives on inquiry teaching in schools. In scientific inquiry and nature of science (pp. 17-35). Springer.

DeBoer, G. E. (2000). Scientific literacy: Another look at its historical and contemporary meanings and its relationship to science education reform. Journal of Research in Science Teaching. https://doi.org/10.1002/1098-2736(200008)

Henn-Reinke, K., \& Chesner, G. (2014). Becoming a Reflective Teacher. In Developing Voice Through the Language Arts. https://doi.org/10.4135/9781483329215.n1 
Husbands, C. (2011). What do history teachers (need to) know? A framework for understanding and developing practice. In I. Davies (Ed.), Debates in history teaching (pp. 84-95). London: Routledge

Kivunja, C. (2014a). Do you want your students to be job-ready with 21st-century skills? Change pedagogies: A pedagogical paradigm shift from Vygotskyian social constructivism to critical thinking, problem-solving, and Siemens' digital connections. International Journal of Higher Education, 3(3), 81.

Kivunja, C. (2014b). Teaching Students to Learn and work Well with 21st Century Skills: Unpacking the Career and Life Skills Domain of the New Learning Paradigm. International Journal of Higher Education. https://doi.org/10.5430/ijhe.v4n1p1

Kivunja, C. (2015). Exploring the pedagogical meaning and implications of the 4Cs "super skills" for the 21st century through Bruner's 5E lenses of knowledge construction improves pedagogies of the new learning paradigm. Creative Education, 6(02), 224.

Kuhn, D. (1993). Science as argument: Implications for teaching and learning scientific thinking. Science Education. https://doi.org/10.1002/sce.3730770306

Lee, P. (2006). Historical Knowledge and the National Curriculum, In. R. Aldrich (Ed.), History in the National Curriculum. London: England: Kogan Page.

Mandelbaum, M. (2019). The anatomy of historical knowledge. JHU Press.

McCombs, B. L. (2017, April). Historical review of learning strategies research: strategies for the whole learner-A tribute to Claire Ellen Weinstein and early researchers of this topic. In Frontiers in Education (Vol. 2, p. 6). Frontiers.

Miller, S. (2016). Implementation of the 4Cs of 21st Century Learning Skills within the Blended Coaching Model. ProQuest Dissertations and Theses.

Moon, J. a. (2004). A Handbook of Reflective and Experiential Learning: Theory and Practice. Theory and Practice. https://doi.org/ISBN-10: 0415335167

National Education Association. (2014). Preparing 21st Century Students for a Global Society: An Educator' s Guide to the "Four Cs." National Education Association.

Ningsih, T. Z., \& Sariyatun, L. A. Development of Portfolio Assessment to Measure the Student's Skill of Using Primary Source Evidence. The New Educational Review, 101.

Ozola, S., \& Riemere, I. (2015). Has the Change of Educational Paradigm Reached Every School and Every Class? Bulgarian Comparative Education Society.

Percival, A. (2013). Becoming a Critically Reflective Teacher. Canadian Journal of University Continuing Education, 24(2). https://doi.org/10.21225/d5b307

Phillips, I. (2008). Teaching history: Developing as a reflective secondary teacher. Teaching History: Developing as a Reflective Secondary Teacher. https://doi.org/10.4135/9781446216545

Reigeluth, C. M., \& Carr-Chellman, A. A. (2009). Instructional-design theories and models. Instructional-Design Theories and Models. https://doi.org/10.4324/9780203872130

Seixas, P. (2017). A Model of Historical Thinking. Educational Philosophy and Theory. https://doi.org/10.1080/00131857.2015.1101363

Shemilt, D. (2000). The caliph's coin: The currency of narrative frameworks in history teaching. In P. N. Stearns, P. Seixas, \& S. Wineburg (Eds.), Knowing, teaching, and learning history: National and international perspectives (pp. 83-101). New York: New York University Press.

Shemilt, D. (2018). Assessment of Learning in History Education: Past, Present, and Possible Futures. The Wiley international handbook of history teaching and learning, 449.

Sutimin, L. A., Joebagio, H., Sariyatun, M., \& Abidin, N. F. (2018). The Development of Deconstructive Learning History Model to Promote the Higher Order Thinking Skills of University Students. The New Educational Review, 51(1), 19-29.

Thorp, R. (2014). Towards an epistemological theory of historical consciousness. Historical 
Encounters.

Tony Ghaye (Routledge. Taylor \& Francis Group). London \& New York. (1988). Teaching and Learning through Reflective Practice. In Teaching and Learning through Reflective Practice: a Practical Guide for Positive Action, the 2nd Edition. https://doi.org/10.4324/9780203833322

Van Boxtel, C., Van der Linden, J., \& Kanselaar, G. (2000). Collaborative learning tasks and the elaboration of conceptual knowledge. Learning and instruction, 10(4), 311-330.

Van Straaten, D., Wilschut, A., \& Oostdam, R. (2016). Making history relevant to students by connecting past, present, and future: a framework for research. Journal of Curriculum Studies. https://doi.org/10.1080/00220272.2015.1089938

Wamba-dia-Wamba, E. (1986). How is Historical Knowledge Recognized? History in Africa, 13, 331-344. DOI:10.2307/3171550

Weinstein, C. E. (1978). Elaboration skills as a learning strategy. Learning strategies (pp. 3155). Academic Press. 